\title{
KEBIJAKAN PENDIDIKAN KEWARGANEGARAAN ERA REFORMASI DI INDONESIA
}

\begin{abstract}
Samsuri
FISE Universitas Negeri Yogyakarta (e-mail: samsuri@uny.ac.id; HP: 081805950338)

Abstract: The Civic Education Policy in the Reform Era in Indonesia. This paper presents a preliminary study on civic education in the national educational policy during the reform era since 1998 in Indonesia. The reform movement has impacts on the reform of national education. Civic education has entered the changing paradigm to build good citizens. In the old paradigm, civic education mainly served the political regime hegemony. Civic education was reduced to value or character education per se. The politics of education in the new era has shifted the paradigm of civic education into the standardization according to democratic citizenship education norms. Civic education focuses more on how the competent teachers transform democratic values democratically.
\end{abstract}

Keywords: reform, civic education, politics of education

\section{PENDAHULUAN}

Studi Hosen (2003) terhadap reformasi politik dan hukum pada pemerintahan Presiden B.J. Habibie (19981999) menunjukkan bahwa upaya reformasi kehidupan politik, hukum, dan pemerintahan yang bersih telah dilakukan dengan intensif. Upaya tersebut kemudian membuahkan hasil berupa reformasi undang-undang tentanghak asasi manusia (HAM), yang mendukung "rule of law," dan proses politik, serta hukum yang mendukung terbentuknya "good governance" seperti pemberantasan korupsi (Hosen, 2003:202).

Dalam kawasan pendidikan, lahirnya Undang-Undang RI No. 20 Tahun 2003 tentang Sistem Pendidikan Nasional telah membawa dampak besar dalam reformasi pendidikan nasional itu sendiri. Di bidang pendidikan kewarganegaraan, dan umumnya dalam kuriku- lum pendidikan formal di sekolah dasar hingga menengah, reformasi tidak hanya terbatas dalam substansi kajian, metode, dan sistem penilaiannya. Pembaharuan pendidikan kewarganegaraan telah bergeser kepada paradigma pembentukan warga negara demokratis sebagaimana idealitas universal dari misi pendidikan kewarganegaraan itu sendiri. Sebagaimana telah diketahui, bahwa paradigma pendidikan kewarganegaraan di Indonesia selama lebih dari tiga dekade era Orde Baru lebih banyak menitikberatkan kepada pembentukan karakter kepatuhan warga negara (siswa) terhadap tafsir resmi rezim politik. Kepatuhan warga negara terhadap tafsir rezim (pemerintah) dianggap sebagai kebajikan atau keutamaan warga negara (civic virtues) yang dilekatkan pada misi pendidikan kewarganegaraan ketika itu. Kepatuhan ini di satu sisi melahirkan 
hipokrisi (kemunafikan) antara wacana dengan tindakan kewargaan (civic action) yang diharapkan. Di sisi lain, ukuran keutamaan tindakan kewargaan sebagai akibat "kemunafikan" tadi ialah lebih banyak dipengaruhi oleh faktor eksternal, seperti tekanan dan kepentingan politik serta ekonomi dalam jabatan publik sehingga tindakan kewargaan yang ditampilkan seorang individu cenderung bersifat semu.

Penggambaran warga negara yang patuh, hegemoni tafsir dan wacana dari negara terhadap warga negara, serta minimnya peluang budaya kritis dalam hubungan masyarakat kewargaan (civil society) dengan masyarakat politik (negara), pada gilirannya telah membentuk budaya politik kewargaan yang tidak kondusif terhadap sistem politik demokrasi. Dalam lingkup pendidikan kewarganegaraan pada era Orde Baru, analisis Kalidjernih (2005:360) terhadap wacana kewarganegaraan dalam bukubuku teks Pendidikan Pancasila dan Kewarganegaraan (PPKn) terbitan resmi Departemen Pendidikan Pendidikan dan Kebudayaan bekerjasama dengan BP-7 menunjukkan bagaimana kuatnya kepentingan rezim membentuk warga negara. Buku-buku teks pendidikan kewarganegaraan tersebut sebagai buku wajib di sekolah menggambarkan kuatnya konsep ideologi negara, konstitusi nasional dan ide negara integralistik, sebagai suatu prinsip panduan dalam kehidupan berbangsa menurut tafsir rezim (Kalidjernih, 2005: 360).

Bertolak dari latar belakang tersebut, artikel ini mengkaji politik kebijakan pendidikan kewarganegaraan era reformasi di Indonesia. Fokus utama tulisan ini ialah bertolak dari asumsi bahwa kebijakan pendidikan akan sangat dipengaruhi oleh sistem politik yang sedang berlaku. Sebagaimana pendapat Cogan (1998:5) tentang pertautan antara pendidikan kewarganegaraan dan kekuasaan, maka kecenderungan Pendidikan Kewarganegaraan di Indonesia sebelum dan selama Orde Baru mencerminkan kepentingan kekuasaan yang cenderung menjadi indoktrinasi dan pembentukan ideologi hegemoni daripada aspek pendidikan itu sendiri. Pada bagian berikutnya, artikel ini memaparkan implikasi kebijakan pendidikan berupa standarisasi isi kajian Pendidikan Kewarganegaraan sebagaimana tampak dalam Peraturan Menteri Pendidikan Nasional RI No. 22 Tahun 2006 tentang Standar Isi untuk Satuan Pendidikan Dasar dan Menengah.

\section{PEMBAHASAN}

Studi tentang kebijakan pendidikan tidak dapat dilepaskan dari pengkajian politik pendidikan itu sendiri. Wong (1995:21) menyebutkan bahwa politik pendidikansebagaisebuah lapangan kajian keilmuan memiliki akar intelektualnya dalam ilmu politik. Dengan demikian, perhatian utama politik pendidikan akan mempergunakan pula domaindomain ilmu politik seperti: kekuasaan (power), pengaruh (influence), konflik (pertikaian), dan alokasi nilai-nilai otoritatif(authoritative allocation of values).

Pada tingkat global, kajian pendidikan kewarganegaraan telah memiliki arti penting. Dengan latar belakang evolusi pemikiran kewarganegaraan di Inggris dari sosiolog Thomas Humprey Marshall, Isin dan Turner (2007:7-14) 
mengungkapkan bahwa agenda penelitian kewarganegaraan di masa depan akan terkait dengan masalah-masalah perjuangan untuk mendapatkan redistribusi, pengakuan (recognition), kewarganegaraan versus hak asasi manusia (citizenship versus human rights), dan kewarganegaraan global versus kewarganegaraan kosmopolitan (global citizenship versus cosmopolitan citizenship). Hal ini akan terkait dengan kenyataan bahwa kewarganegaraan dan hak asasi manusia merupakan sesuatu yang penting untuk mewujudkan masyarakat demokratis yang efektif. Dengan demikian, "Citizenship is essential for cultivating civic virtues and democratic values" (Isin dan Turner, 2007:5). Pada bagian lain, dari pengalaman pengembangan pendidikan kewarganegaraan di Inggris sejak lahirnya dokumen Crick Report (Quality Curriculum Association, 1998) tentang pendidikan kewarganegaraan untuk sekolah-sekolah di Kerajaan Inggris, Osler dan Starkey (2006: 435-439) menemukan kecenderungan penelitian dan kajian pendidikan kewarganegaraan dengan tema-tema global injustice and inequality, globalization and immigration, concern about civic and political engagement, youth deficit, the end of Cold War, and, anti-democratic and racial movements.

Sebuah laporan Komisi Internasional UNESCO tentang Pendidikan Abad 21 (Report to UNESCO of The International Commission on Education for the Twentyfirst Century), yang diketuai Jacques Delors, bertajuk Learning: The Treasure Within (1996), tentang arti penting pendidikan kewarganegaraan menarik untuk dicermati. Selain telah menjadi tugas Komisi tersebut untuk merumuskan arti penting pendidikan memasuki milenium ketiga, ada satu bagian penting dari laporan tersebut yang secara terbuka menyebutkan arti penting partisipasi demokrasi dari warga negara dalam kehidupan global. Hal ini ditegaskan bahwa,

"As education for citizenship and democracy is par excellence an education that is not restricted to the space and time of formaleducation, it is also important for families and other members of the community to be directly involved" (Delors, et.al., 1996:62).

Dengan demikian, pendidikan kewarganegaraan tidak hanya berlaku di lingkungan pendidikan formal, namun juga penting bagi keluarga dan anggota masyarakat untuk terlibat secara langsung.

Pada bagianlain, laporan komisi tersebut juga mengukuhkan arti penting partisipasi demokratis melalui pendidikan kewarganegaraan dan praktik kewarganegaraan dengan menekankan perlunya sebuah hubungan sinergis antara pendidikan dan praktik demokrasi partisipatori. Dengan demikian, dapat dikatakan bahwa dalam pendidikan kewarganegaraan:

"... not only should everyone be trained to exercise their rights and fulfil their duties, but use should be made of lifelong education in order to build an active civil society which, occupying the middle ground between scattered individuals and adistant political authority, would enable each person to shoulder his or her share of responsibility in the community, with a view to achieving true solidarity. Thus, the education of each citizen must continue throughout his or her life and become part of the basic framework of civil society and living democracy (Delors, et.al., 1996: 63). 
Perhatian terhadap arti penting pendidikan kewarganegaraan tersebutmemperkuat pandangan yang menyatakan bahwa persoalan kehidupan warga negara dalam sistem nilai demokrasi telah mengalami "globalizing" atau "globalized." Patrick (2002:1) menyebutkan bahwa hentakan global dari ide demokrasi selama perempat terakhir abad ke-20 telah membuka dunia luas dengan minat baru terhadap pendidikan kewarganegaraan. Para pemimpin di bekas negara-negara komunis telah mewujudkan pembangunan demokrasi yang otentik yang tergantung kepada pembangunan melalui pendidikan yang menjadikan warga negara kompeten dan bersungguh-sungguh. Mereka tahu apa itu demokrasi, bagaimanamelakukannya, dan mengapa demokrasi itu baik, atau paling sedikit lebih baik dari alternatif tipe-tipe sistem politik yang pernah ada (Patrick, 2002:1). Munculnya perhatian internasional tentang pendidikan demokrasi melalui pendidikan kewarganegaraan sebagai salah satu sarana utamanya telah merangsang pemikiran masyarakat internasional. Organisasi antarpemerintah seperti Uni Eropa maupun organisasi internasional masyarakat kewargaan seperti Civitas, menunjukkan indikator lainnya. Keduanya menunjukkan bahwa demokrasi sebagai sebuah nilai universal tidak akan mungkin menjadi satu kenyataan global, sebagai common sense masyarakat dunia, tanpa ada sebuah ikhtiar yang intensif dan serius secara internasional melalui apa yang disebut pendidikan.

Sejalan dengan tuntutan global terhadap peran penting pendidikan kewarganegaraan, Indonesia telah mengalami pergeseran paradigmatik pendidikan kewarganegaraan. Paradigma baru ini memfokuskan diri pada upaya membentukpesertadidik sebagai masyarakat kewargaan (civil society) dengan memberdayakan warga negara melalui proses pendidikan agar dapat berpartisipasi aktif dalam sistem pemerintahan negara yang demokratis(Muchson, 2004:32). Sehubungan dengan paradigma baru itu, kajian pendidikan kewarganegaraan bertujuan membentuk para peserta didik agarmemiliki kompetensi sebagai "warga negara yang baik" dalam hal (1) civic knowledge (pengetahuan kewarganegaraan);(2) civic skills (ketrampilan kewarganegaraan); dan (3) civic dispositions (karakter kewarganegaraan) (Muchson, 2004:33).

Kajian Pendidikan Kewarganegaraan yang mulai diperkenalkan menjelang 2004(kemudian dikenal sebagaiKurikulum Berbasis Kompetensi, KBK) oleh banyak kalangan dinilai sangat kering dengan muatan nilai moral, khususnya nilai moral Pancasila, namun sarat dengan kajian konsep-konsep politik dan hukum. Sebelum KBK, mata pelajaran pendidikan kewarganegaraan dalam PMP ataupun PPKn didominasi oleh materi nilai-nilai moral Pancasila (Langenberg, 1990:132). Hal ini mencerminkan bahwa PMP atau PPKn lebih merupakan pendidikan budi pekerti daripada pendidikan kewarganegaraan yang sesungguhnya. Cakupan substansi kajian dan kompetensi kewarganegaraan yang diharapkan dari PKN itu sendiri, yaitu upaya pembentukan warga negara yang baik (good citizen) dalam warga negara demokratis yang bertanggung jawab dan berpartisipasi aktif dalam 
kehidupan sistem politik negaranya, disederhanakan hanya menjadi sematamata menghapalkan nilai-nilai moral, bagaimana harus berbuat baik dan tidak berbuat buruk dalam arti afeksimoral secara formal.

Sementara itu, ada kesenjangan pula antara pembelajaran pendidikan kewarganegaraan di lembaga pendidikan formal (sekolah) dengan keadaan kongkret di masyarakat, sehingga ada kecenderungan bahwa pendidikan kewarganegaraan tercerabut dari akar konteks kehidupan siswa sebagai warga negara. Sebagaimana pengkajian oleh para sarjana (Kalidjernih, 2005; Cholisin, 2004) terhadap fungsi pendidikan kewarganegaraan pada masa Orde Baru, semakin memperkuatalasan bahwa peran pendidikan kewarganegaraan semata sebagai sarana penyaluran kepentingan rezim, pengagungan harmoni (selaras, serasi, dan seimbang) dengan menolak pengakuan terhadap perbedaan dan konflik.

Keadaan pendidikan kewarganegaraan yang demikian, telah mengalami pergeseran paradigmatis seiring dengan tuntutan reformasi. Dalam makalah ini, reformasi pendidikan diartikan sebagai upaya pembaharuan berupa perubahan dan dan perbaikan ke arah kemajuan dalam dunia pendidikan secara komprehensif. Dengan demikian, reformasi mencakup proses dan hasil.

Proses reformasi ini berkait erat dengan proses politik pendidikan dan mengikuti mekanisme pembuatan keputusan, yakni mulai dari tahap input, process, dan output. Margaret S. Archer (1985:39)menjelaskanbahwa politik pendidikan sebagai:
"... the attempts (conscious and organized to some degree) to influence the inputs, processes and outputs of education, whether by legislation, pressure group or union action, experimentation, private investment, local transactions, international innovation or propaganda."

Dari pengertian tersebut, tampak jelas bahwa reformasi pendidikan akan melibatkan banyak elemen baik di tingkat suprastruktur maupun infrastruktur, yang tujuan utamanya ialah terjadi perubahan dan pembaharuan di bidang pendidikan.

Di kalangan sarjana politik pendidikan dikenal dua kelompok aliran (Wong, 1995:24-25) yang mengajukan konseptualisasi struktur kekuasaan dan praktik demokrasi. Pertama, kelompok "elitis," mengajukan kerangka yang memusatkan kepada bagaimana komunitas ekonomi dan elite politik secara erat mendominasi pembuatan kebijakan pendidikan. Kedua, kelompok "pluralis," perspektifnya memfokuskan kepada kebijakan-kebijakan pendidikan (sekolah) yang dipengaruhi oleh persaingan kepentingan, perselisihan partisan, dan pemilihan terbatas.

Sejalan dengan teorisai Easton (1966: 339) terhadap kajian sistem politik dengan menganalisis bagaimana keputusan-keputusan otoritatif dibuat, analisis kebijakan politik pendidikan akan terkait erat dengan proses-proses pembuatankeputusan politik(kebijakan pendidikan). Dalam proses pembuatan keputusan itulah kerja mekanisme politik (input-proses-output) amat menentukan akomodasi dan agregasi nilai-nilai yang diperjuangkan baik oleh pemerintah, kelompok kepentingan, dan organisasi 
masyarakat lainnya. Proses akomodasi dan agregasi kepentingan memerlukan berbagai perundingan.

Archer (1985:42-47) mengelompokkan tiga tipe negosiasi dalam analisis politik pendidikan: tipe "internal initiation," tipe "external transaction," dan tipe "political manipulation." Dalam tipe inisiasi internal upaya perubahan kebijakan pendidikan datang dari kalangan profesi pendidikan, seperti organisasi guru atau kelompok sarjana pendidikan yang relevan. Tujuan inisiatif dapat beragam, namun akan selalu tergantung kepada profesi yang diperolehnya, dan hak-hak legal untuk mewujudkannya dalam kenyataan sehari-hari. Untuk ini, inisiasi internal perlu melakukan pertukaran sumber daya dengan kelompok-kelompok kepentingan eksternal. Dalam tipe transaksi eksternal, negosiasi oleh kelompok internal pendidikan akan melibatkan kelompok kepentingan eksternal. Pada tipe manipulasi politik, proses negosiasi dimaksudkan untuk mempengaruhi antara pemerintah dan kelompok profesi di satu pihak, dan tipe pertama dengan tipe ketiga, di pihak lain untuk memberikan penolakan atau dukungan terhadap alokasi nilai yang diperjuangkan sebagai kebijakan publik.

\section{KEBIJAKAN PENDIDIKAN KEWAR- GANEGARAAN ERA REFORMASI DI INDONESIA}

Kebijakan pendidikan tentang pendidikan kewarganegaraan di sejumlah negara, seperti di Inggris (di bawah pemerintahan Partai Buruh sejak 1997) ataupun Afrika Selatan (sejak berakhir pemerintahan apartheid sejak 1994), lahir dari kemauan (kepentingan) politik pemimpin nasional dan gerakan masyarakat kewargaan untuk membangun tatanan kehidupan bernegara yang sehat. Dalam konteks Indonesia, kebijakan pendidikan kewarganegaraan sulit ditemukan inspirasi dan sumber motivasinya yang berasal dari kekuatan politik (partaipolitik) baik di dalam parlemen maupun diluarparlemen. Upaya-upayalegislasi, baik di DPR maupun MPR era reformasi terhadap kebijakan pendidikan nasional secara umum sama sekali tidak menyinggung secara khusus pentingnya reformasi pendidikan kewarganegaraan.

MPR sebelum amandemen ketiga (2001) dan keempat (2002), sebagai lembaga tertinggi negara memang telah melahirkan produk hukum yangmembuka jalan refomasi pendidikan secara menyeluruh. Perdebatan di persidangan MPR 1999 dan kemudian dirumuskan dalam dokumen GBHN 1999 secara tegas menuntut reformasi di bidang pendidikan antara lain melalui pembaharuan kurikulum dan instrumen pendidikan lainnya. Berturut-turut dalam amandemen Pasal 31 UUD 1945 secara tegas memposisikan aturan pokok kebijakan pendidikan nasional. Konstitusi (UUD 1945) sebagai dokumen rujukan hukum tertinggi secara terang benderangpula menegaskan bagaimana peran negara dan warga negara di bidang pendidikan diatur dalam pasal tersebut.

Proses politik untuk mereformasi kebijakan pendidikan nasional tampak dalam pemahasan RUU Sisdiknas 2003 di DPR. RUU ini menjadi salah satu contoh bagaimana kebijakan pendidikan lahir dari kemauan politik lewat usul 
inisiatif DPR di Komisi VI. Cerminan aspirasi politik rakyat melalui para anggota DPR memberikan gambaran bahwa kehendak kuat untuk mereformasi sistem pendidikan nasional menapak kuat setelah era reformasi.

UU Sisdiknas 2003 sebagaimana UU Sisdiknas 1989 mendudukan posisi PKn sebagai mata kajian pengembangan kepribadian mulai dari jenjang pendidikan dasar hingga pendidikan tinggi, bersama-sama dengan mata pelajaran agamadan bahasa. Berbeda dengan UU Sisdiknas 1989 yang selain mencantumkan Pendidikan Pancasila dan Pendidikan Kewarganegaraan, maka dalam UU Sisdiknas 2003 tidak ada lagi nama mata pelajaran Pendidikan Pancasila, tetapi hanya Pendidikan Kewarganegaraan. UU Sisdiknas 2003 sudah dengan tepat tidak mencantumkan lagi Pendidikan Pancasila dalam kurikulum pendidikan nasional, karena penamaan "Pancasila" di belakang kata "pendidikan" justru menurunkan posisi Pancasila sebagai dasar negara, yang sebenarnya tidak boleh direduksi menjadi pelabelan-pelabelan, seperti ekonomi Pancasila, demokrasi Pancasila.

Bagaimanapun, pendidikan kewarganegaraan di negara manapun di dunia, yang menjadi great ought-nya ialah dasar sistem politik dari negara yang bersangkutan. Indonesia sudah pasti dasar kehidupan berbangsa bernegaranya ialah Pancasila, yang dengan sendirinya Pendidikan Kewarganegaran sebagai upaya pembentukan warga negara yang akan mendasarkan diri kepada Pancasila sebagai dasar negara. Ini juga sejalan dengan kemauan politik MPR pada Sidang Istimewa 1998 yang menegaskan kembali Pancasila sebagai dasar negara dan mencabut Ketetapan MPR 1978 tentang P4. Sebagaimana diketahui bahwa P4 merupakan materi pokok dari pendidikan kewarganegaraan selama Orde Baru (baik dalam nama PMP maupun PPKn). Penjelasan di atas memperlihatkan bahwa reformasi pendidikan khususnya pendidikan kewarganegaraan tidak dapat dilepaskan dari kepentingan politik nasional. Dengan demikian, sistem politik sangat kuat mempengaruhi arah politik pendidikan.

Setelah bergulirnya kebijakan Standar Nasional Pendidikan melalui Peraturan Pemerintah No. 19 Tahun 2005, proses pembuatan kebijakan pendidikan nasional tidak lagi semata-mata diampu oleh Pemerintah melalui Departemen Pendidikan Nasional. Kehadiran Badan Standar Nasional Pendidikan (BSNP) di satu sisi menjadi lembaga penyusun kebijakan tentang standarisasi pendidikan, namun di sisi lain badan ini juga nampaknya telah menggeser peran alat birokrasi Depdiknas seperti Pusat Kurikulum.

Pada bagian lain, UU Sisdiknas 2003 kemudian melahirkan kebijakan yang menonjol seperti standar nasional pendidikan. Pembentukan BSNP berdasarkan PP19 Tahun 2005 dimaksudkan untuk mewujudkan standar nasional tersebut. Implikasi dari kehadiran BSNP ialah bahwa terdapat pergeseran pembuatan keputusan dalam kebijakan pendidikan terutama terkait dengan kurikulum pendidikan nasional. Sebelum PP 19 Tahun 2005 lahir, keputusan-keputusan untuk memproduksi kebijakan kurikulum hulunya berada di Balitbang melalui Pusat Kurikulum. Namun sete- 
lah PP itu lahir, Pusat Kurikulum bekerja pada aspek teknis kebijakan yang disusun oleh BSNP melalui Peraturan Menteri Pendidikan Nasional, seperti melakukan kajian kebijakan SI atau pemberian bantuan teknis KTSP dan menemukan inovasi-inovasi kurikulum untuk melaksanakan SI.

Antara SI dan SKL Mata Pelajaran PKn yang diatur dalam Permendiknas No. 22 dan No. 23 Tahun 2006 menunjukkan bagaimana produk kebijakan pendidikan ini menyesuaikan diri dengan kebutuhan dan tuntutan reformasi nasional. Sebagaimana diketahui bahwa sebelum era reformasi kurikulum bersifat sentralistik, dan kontennya menunjukkan kepentingan politik rezim. Dengan demikian, tesis Cogan (1998) yang menyatakan bahwa kepentingan kekuasaan rejim politik nasional terhadap kebijakan pendidikan kewarganegaraan sebelum era reformasi adalah tepat. $\mathrm{Na}$ mun, tesis tersebut menjadi tidak relevan untuk menunjuk SI dan SKL Mata Pelajaran PKn 2006. SI dan SKL Mata Pelajaran PKn justru tunduk dengan kepentingan "rezim standardisasi" yang secara universal telah dikembangkan oleh berbagai macam teorisasi maupun model-model Pendidikan Kewarganegaraan di sejumlah negara. "Rezim standardisasi" yang dimaksud ialah bahwa standar minimal kajian pendidikan kewarganegaraan yang mesti dimuat dalam SI Mata Pelajaran PKn telah terpenuhi. Standar minimal tersebut secara konseptual memenuhi komponen-komponen kompetensi kewarganegaraan serta substansi kajian PKn sebagaimana dikembangkan oleh CCE (1994) maupun sejumlah pengembang $\mathrm{PKn}$, seperti Print (1999) dan Patrick (1999).

Di bagian lain, standardisasi pendidikan nasional juga menunjukkan bahwa kebijakan pendidikan menunjukkan keberhasilan tuntutan politik, tuntutan globalisasi dan tuntutan kemajuan (progress) (Tilaar, 2006: 76-77). Standardisasi nasional pendidikan sebenarnya akan menjadi lebih bermakna penting bagi perbaikan sistem pendidikan nasional, jika keberadaan BSNP bukan untuk menjadi alat kekuasaan pemerintah melalui pendidikan.

Sebelum BSNP dibentuk, kebijakankebijakan tentang kurikulum nasional antara lainbanyak lahir dan dikembangkan oleh Pusat Kurikulum. Perihal ini, amat menarik untuk membandingkan keadaan pengembangan kebijakan standardisasi isi diIndonesia, terutama standarisiPendidikan Kewarganegaraan dengan hasil penelitian Kidwell (2005: ix-x) yang mengkaji hubungan antara kebijakan negara bagian di Amerika Serikat yang secara eksplisit menyajikan pendidikan kewarganegaraan sejak Taman Kanak-kanakhinggaKelas 12 (K-12) dan keberadaan kurikulumnya. Hasil penelitian terhadap kebijakan pendidikan keseluruhan dari 50 negara bagian di Amerika Serikat menunjukkan bahwa perlu kebijakan negara bagian yang efektif sebagai basis bangunan kurikulum pendidikan kewarganegaraan yang berkualitas tinggi dan sistem pengajarannya. Temuan penelitian itu juga memasukan hasil identifikasi kondisi kritis terhadap pelaksanaan kebijakan secara efektif. Salah satu keadaan tersebut adalah komponen-komponen pendidikan kewarganegaraan berbasis standar yang diim- 
plementasikan secara intensional dan perencanaan sistematis. Hal kedua berkaitan dengan disiplin pendidikan kewarganegaraan yang memerlukan kecakapan-kecakapan kewarganegaraan (civic skills) di luar memorisasi dan hapalan bahan ajar. Hasil penelitian juga menemukan kesepakatan nasional atas standarisasi sebagai seperangkat indikator untuk indeks siswa terhadap pembelajaran pendidikan kewarganegaraan.

Standardisasi isi pendidikan kewarganegaraan sebagaimana tampak dalam Lampiran Peraturan Menteri Pendidikan Nasional RI No. 22 Tahun 2006 memberikan pemaknaan sebagai berikut. Pertama, orientasi pendidikan kewarganegaraan telah berpijak kepada kajian antardisiplin yang jelas, yaitu bidang politik, hukum, dan nilai moral (Pancasila). Hal ini nampak pada struktur materi kajian Pendidikan Kewarganegaraan sebagaimana dirangkum dalam Tabel 1 . Pada kurikulum-kurikulum sebelumnya kajian Pendidikan Kewarganegaraan tidak memiliki akar penjelasan ilmiah yang memadai karena mendasarkan diri kepada nilai-nilai yang merupakan tafsir ideologi yang dibuat oleh rezim kekuasaan yang ada. Tabel 2 menunjukkan bagaimana Pancasila yang ditafsirkan dalam bentuk P4 dijadikan inti kajian Pendidikan Kewarganegaraan dalam matapelajaran PPKn. Tidak ada yang buruk dengan nilai-nilai tersebut, hanya saja ini berakibat kepada anggapan bahwa Pendidikan Kewarganegaraan ialah pendidikan budi pekerti atau semata pendidikan moral.

Penelitian Kalidjernih (2005) menunjukkan bahwa selama Orde Baru di Indonesia melalui pendidikan kewarga- negaraan nampak betapa kuatnya kepentingan rezim tersebut. Hal itu nampak dalam buku-buku teks pendidikan kewarganegaraan terbitan Departemen Pendidikan dan Kebudayaan bersama BP-7 Pusat sebagai buku wajib di sekolah, yang menggambarkan kuatnya konsep ideologi negara, konstitusi nasional dan ide negara integralistik, sebagai suatu prinsip panduan dalam narasi bangsa. Penelitian Kalidjernih ini nampak memperkuat tesis Bourchier (2007: 346-365)yangmenjelaskan pengaruh pemikiran integralistik Hegelian dalam rezimentasi pendidikan era Orde Baru, khususnya melalui pendidikan kewarganegaraan yang sarat kepentingan rezim (seperti dalam bentuk Penataran P4, mata pelajaran PMP dan PPKn di sekolah dasar dan menengah, serta Pendidikan Kewiraan di perguruan tinggi).

Kedua, akibatdaripengkajian Pendidikan Kewarganegaraan yang mengacu kepada standar keilmuan yang umum berlaku sebagai pendidikan kewarganegaraan di negara-negara demokratis ialah bahwa standar isi kajian tidak lagi bergantung pada pergantian rezim. Sebagaimana telah diketahui bahwa di masa sebelumnya, terdapat stigma yang dilekatkan kepada mata pelajaran Pendidikan Moral Pancasila (PMP) atau Pendidikan Pancasila dan Kewarganegaraan (PPKn), termasuk pula kepada institusi lembaga pendidikan tenaga kependidikan (LPTK) bernama IKIP(STKIP atau FKIP Universitas) yang di dalamnya terdapat Jurusan/Program Studi PPKn. Stigma negatif diarahkan kepada matapelajaran dan jurusan ini karena tidak berhasil menanamkan moral Pancasila, dengan makin maraknya korupsi 
dan krisis moral para pejabat serta politisi. Ini selain tidak adil juga terkesan bahwa tanggung jawab mendidik moral bangsa dibebankan hanya kepada lembaga ini. Padahal, pendidikan sebagai tanggung jawab negara sejak Indonesia merdeka selalu mengalami marjinalisasi dalam kebijakan nasional seperti anggaran belanja negara (APBN) yang kurang dari 20 persen. Sementara itu, Pendidikan Kewarganegaraan dalam PPKn sendiri meski katanya menjadi mata kajian penting seperti disebut dalam bagian UU No. 2 Tahun 1989 tentang Sistem Pendidikan Nasional dan Garis-garis Besar Haluan Negara (GBHN) di masa Orde Baru, namun nasibnya sekadar alat pembangunan.

Tabel 1. Inti Kajian dan Uraian Materi Pendidikan Kewarganegaraan Tahun 2006 di Indonesia

\begin{tabular}{cl}
\hline Topik Inti Kajian & Uraian Materi Kajian \\
\hline 1. Persatuan dan & Hidup rukun dalam perbedaan; Cinta lingkungan; Kebanggaan seba- \\
Kesatuan Bangsa & $\begin{array}{l}\text { gai bangsa Indonesia; Sumpah Pemuda; Keutuhan Negara Kesatuan } \\
\text { Republik Indonesia; partisipasi dalam pembelaaan negara; sikap po- } \\
\text { sitif terhadap Negara Kesatuan Republik Indonesia; keterbukaan dan }\end{array}$ \\
& jaminan keadilan.
\end{tabular}

2. Norma, Hukum, Tertib dalam kehidupan keluarga; tertib di sekolah; norma yang berladan Peraturan ku di masyarakat; peraturan-peraturan daerah; norma-norma dalam kehidupan berbangsa dan bernegara; sistem hukum dan peradilan nasional; hukum dan peradilan internasional.

3. Hak Asasi Hak dan kewajiban anak; Hak dan kewajiban anggota masyarakat; Manusia Instrumen nasional dan internasional HAM; Pemajuan, dan penghormatan HAM.

4. Kebutuhan Warga Hidup gotong royong; harga diri sebagai warga masyarakat; kebebasNegara an berorganisasi; kemerdekaan mengeluarkan pendapat; menghargai keputusan bersama; prestasi diri; persamaan kedudukan warga negara.

5. Konstitusi Negara Proklamasi kemerdekaan dan konstitusi pertama; konstitusi-konstitusi yang pernah digunakan di indonesia; hubungan dasar negara dengan konstitusi.

6. Kekuasaan dan Pemerintahan desa dan kecamatan; pemerintahan daerah dan otonoPolitik mi; pemerintah pusat; demokrasi dan sistem politik; budaya politik; budaya demokrasi menuju masyarakat madani; sistem pemerintahan; pers dalam masyarakat demokrasi.

7. Pancasila Kedudukan Pancasila sebagai dasar negara dan ideologi negara; proses perumusan Pancasila sebagai dasar negara; Pengamalan nilainilai Pancasila dalam kehidupan sehari-hari; Pancasila sebagai ideologi terbuka.

8. Globalisasi Globalisasi di lingkungannya; politik luar negeri indonesia di era globalisasi; dampak globalisasi; hubungan internasional dan internasional; dan mengevaluasi globalisasi.

Sumber: Peraturan Menteri Pendidikan Nasional No. 22 Tahun 2006 tentang Standar Isi untuk Satuan Pendidikan Dasar dan Menengah 
Tabel 2. Konsep Nilai, Moral, dan Norma Pancasila dalam GBPP PPKn SMA dan Pola Penyebaran serta Acuan Pengembangannya

\begin{tabular}{|c|c|c|c|}
\hline Sila-Sila Pancasila & $\begin{array}{c}\text { Pokok Bahasan } \\
\text { Kelas I }\end{array}$ & $\begin{array}{c}\text { Pokok Bahasan } \\
\text { Kelas II }\end{array}$ & $\begin{array}{l}\text { Pokok Bahasan } \\
\text { Kelas III }\end{array}$ \\
\hline $\begin{array}{l}\text { Ketuhanan Yang } \\
\text { Maha Esa }\end{array}$ & $\begin{array}{l}\text { 1. Toleransi } \\
\text { 2. Kerukunan } \\
\text { 3. Keselarasan }\end{array}$ & $\begin{array}{l}\text { 4. Ketaqwaan } \\
\text { 5. Saling menghormati } \\
\text { 6. Kerjasama }\end{array}$ & $\begin{array}{l}\text { 7. Kerukunan } \\
\text { 8. Nilai Luhur } \\
\text { 9. Keyakinan }\end{array}$ \\
\hline \multirow[t]{3}{*}{$\begin{array}{l}\text { Kemanusiaan yang } \\
\text { adil dan beradab }\end{array}$} & 10. Menghargai & 13. Keramah tamahan & $\begin{array}{l}\text { 16. Keadilan- } \\
\text { kebenaran }\end{array}$ \\
\hline & $\begin{array}{l}\text { 11. Persamaan derajat } \\
\text { martabat }\end{array}$ & 14. Keserasian hidup & 17. Kecintaan \\
\hline & 12. Kasih sayang & $\begin{array}{l}\text { 15. Martabat dan harga } \\
\text { diri }\end{array}$ & 18. Tenggang rasa \\
\hline Persatuan Indonesia & $\begin{array}{l}\text { 19. Cinta tanah air } \\
\text { 20. Patriotisme } \\
\text { 21. Kewaspadaan }\end{array}$ & $\begin{array}{l}\text { 22. Kesatuan } \\
\text { 23. Kesetiaan } \\
\text { 24. Kesatuan-persatuan }\end{array}$ & $\begin{array}{l}\text { 25. Kebanggaan } \\
\text { 26. Kebulatan tekad } \\
\text { 27. Kesetiaan }\end{array}$ \\
\hline $\begin{array}{l}\text { Kerakyatan yang di- } \\
\text { pimpin oleh hikmat }\end{array}$ & 28. Kebijaksanaan & $\begin{array}{l}\text { 31. Keikhlasan dan } \\
\text { Kejujuran }\end{array}$ & 34. Ketaatan \\
\hline $\begin{array}{l}\text { kebijaksanaan dalam } \\
\text { permusyawaratan/ } \\
\text { perwakilan }\end{array}$ & $\begin{array}{l}\text { 29. Musyawarah } \\
\text { 30. Ketertiban }\end{array}$ & $\begin{array}{l}\text { 32. Tanggung jawab } \\
\text { 33. Nilai Lebih Demokrasi } \\
\text { Pancasila }\end{array}$ & $\begin{array}{l}\text { 35. Keikhlasan } \\
\text { i 36. Pengendalian di }\end{array}$ \\
\hline $\begin{array}{l}\text { Keadilan Sosial bagi } \\
\text { seluruh Rakyat } \\
\text { Indonesia }\end{array}$ & $\begin{array}{l}\text { 37. Pengabdian } \\
\text { 38. Kegotongroyongan } \\
\text { 39. Kepentingan umum }\end{array}$ & $\begin{array}{l}\text { 40. Kedisiplinan } \\
\text { 41. Kesederhanaan } \\
\text { 42. Kecermatan dan hidup } \\
\text { hemat }\end{array}$ & $\begin{array}{l}\text { 43. Keadilan sosial } \\
\text { 44. Bekerja sama } \\
\text { 45. Tolong menolon }\end{array}$ \\
\hline
\end{tabular}

Sumber: Djahiri dan Wahab (1996:85)

Ketiga, akibat lain dari pengkajian Pendidikan Kewarganegaraan yang mengacu kepada standar keilmuan ialah makin jelas siapa saja yang berhak melakukan proses pembelajaran Pendidikan Kewarganegaraan di sekolah. Sangat mustahil pembelajaran kedelapan topik dari standar kajian Pendidikan Kewarganegaraan itu dapat mencapai sasarannya (standar kompetensi lulusan) jika sang pendidik (guru) tidak memahami substansi dan komponen kajiannya. Di masa lalu, ada adagium yang cenderung melecehkan profesi guru Pendidikan Kewarganegaraan. Hal ini ter- bukti bahwa siapapun dapat mengajarkan materi Pendidikan Kewarganegaraan (baikdalammatapelajaran PMP maupun PPKn ketika itu), meskipun bukan dari lulusan Program Studi Pendidikan Kewarganegaraan LPTK. Seiring dengan kebijakan standarisasi tenaga pendidik, maka ada relevansi antara misi pembentukan warga negara demokratis melalui pembelajaran Pendidikan Kewarganegaraan dengan pelaku Pendidikan Kewarganegaraan itu sendiri yang memiliki kompetensi profesional (di samping aspek pedagogik, personal, dan sosial) se- 
bagaimana harapan normatif UU RI No. 14 Tahun 2005 tentang Guru dan Dosen.

Dari penjelasan tersebut di atas, reformasipendidikan kewarganegaran dapat dimaknai sebagai titik temu kepentinganduahal. Secara internal, perubahan politik melalui gerakan reformasi nasional telah mendorong pembaharuan pendidikan kewarganegaraan sebagai bagian dari gerakan reformasi pendidikan nasional secara keseluruhan. Pilihan reformasi pendidikan kewarganegaraan tidak semata-mata merubah paradigma kajian yang menekankan kepada penguasaan subject matters yang dominan aspek afektif, tetapi bergeser (berganti) kepada paradigma kajian yang menekankan kepada penguasaan kompetensi kewarganegaraan bagi para siswa meliputi aspek pengetahuan (materi kajian), aspek keterampilan/kecakapan dan aspek perilaku.

Secara eksternal, wacana penguatan masyarakatkewargaan pasca-Perang Dingin di sejumlah negara bekas komunis di Eropa Timur ataupun rezim otoriter di Afrika Selatan telah mendorong perkembangan pendidikan kewarganegaraan sebagaicara membentuk warga negara demokratis. Dengan disponsori oleh asosiasi profesi seperti Center for Civic Education(CCE) Calabasas, Amerika Serikat,model-model pendidikan kewarganegaraan yang menyokong penguatan masyarakat kewargaan di Eropa Timur sangat gencar dilakukan. Upaya CCE untuk menyokong reformasi pendidikan kewarganegaraan di Indonesia pernah dilakukan melalui Center for Indonesia Civic Education (CICED) ataupun ICCE Universitas Islam Negeri Syarif Hidayatullah Jakarta. Dalam kasus In- donesia, reformasi pendidikan kewarganegaraan yang melibatkan peran CCE tidak serta-merta menembus ke lembaga pemerintah, Departemen Pendidikan Nasional. Akibatnya, reformasi pendidikan kewarganegaraan dengan paradigma baru itu tidak secara murni lahir dariinisiatifdepartemen pemerintah tersebut, tetapi "infiltrasi" darijaringan akademisi di bawah bendera pusat kajian pendidikan kewarganegaraan semacam CICED. Dengan demikian, ada keterkaitan antara faktor internal dan eksternal terhadap proses reformasi pendidikan kewarganegaraan, di mana pembaharuan lahir dan digerakkan oleh gerakan masyarakat kewargaan berbasis kampus, dengan memanfaatkan forum-forum Departemen Pendidikan Nasional.

Di luar kedua faktor tersebut, lahirnya standardisasi pendidikan kewarganegaraan sebagaimana standardisasi untuk mata pelajaran lainnya dalam Peraturan Menteri Pendidikan Nasional No. 22 Tahun 2006, menandai bahwa kebijakan pendidikan nasional Indonesia telah menyesuaikan diri dengan tuntutan "neo-liberal" pendidikan. Indikasi "neoliberal" dunia pendidikan ialah dengan diterimanya standardisasi untuk semua urusan, termasuk standar isi dan kompetensi lulusan suatu mata pelajaran. Dengan demikian dapat dipastikan bahwa secara substansial pendidikan kewarganegaraan di Indonesia akan sama ketika berbicara hak asasi manusia, konstitusi,masyarakat kewargaan, institusi politik, sistem demokrasi, dan rule of law. Hal pembeda hanyalah pada konteks nasional apa topik-topik tadi dikaji dalam pendidikan kewarganegaraan. 


\section{PENUTUP}

Kebijakan tentang Pendidikan Kewarganegaraan dipersekolahan Indonesia era reformasi tidak dapat dilepaskan dari politik nasional yang melatarinya. Tuntutan reformasi di segala aspek kehidupanberbangsa dan bernegara, pada gilirannya telah membawa perubahan paradigmatik kajian dan pembelajaran Pendidikan Kewarganegaraan di Indonesia, standardisasi kompetensi lulusan, dan, tenaga pengajar (guru). Hal ini, di satu sisi semakin memantapkan kedudukan Pendidikan Kewarganegaraan sebagai mata pelajaran pengembangan kepribadian (sebagai warga negara yang baik). Di sisi lain, merupakan tantangan bagi para pengembang Pendidikan Kewarganegaraan agar di masa depan pengembangan substansi kajiannya tidak tergantungkepada pergantian rezim kekuasaan.

\section{UCAPAN TERIMA KASIH}

Artikel ini merupakan penulisan ulang dari sebagian naskah disertasi di Program Studi Pendidikan IPS Sekolah Pascasarjana UPI Bandung. Penulis menyampaikan ucapan terima kasih kepada para mitra bestari dan reviewer yang telah memberikan kritik terhadap naskah awal artikel ini.

\section{DAFTAR PUSTAKA}

Archer, M. S. 1985. "Educational Politics: A Model for Their Analysis." in: Ian McNay and Jenny Ozga. (eds.). Policy-Making in Education. Oxford: Pergamon Press and The Open University.
Bourchier, D. 2007. Lineages of Organicist Political Thought in Indonesia. (diterjemahkan oleh Agus Wahyudi sebagai Pancasila Versi Orde Baru dan Asal Muasal Negara Organis (Integralistik). Yogyakarta: Aditya Media Yogyakarta dan Pusat Studi Pancasila Universitas Gadjah Mada.

Cholisin. 2004. “Konsolidasi Demokrasi Melalui Pengembangan Karakter Kewarganegaraan." Jurnal Civics, 1(1), 14-28.

Cogan, J. J. 1998. “Citizenship Education for the 21st Century: Setting the Context". in: John J. Cogan dan Ray Derricott. Citizenship for the 21st Century: An Introduction Perspectives on Education. London: Kogan Page Ltd.

Delors, J., et.al. 1996. Learning: the Treasure Within, Report to UNESCO of The International Commission on Education for the Twenty-first Century. Paris: UNESCO.

Djahiri, Ahmad Kosasih dan Wahab, Abdul Azis. 1996. Dasar dan Konsep Pendidikan Moral. Jakarta: Departemen Pendidikan dan Kebudayaan Ditjen Dikti Proyek Pendidikan Tenaga Akademik.

Easton, D. 1966. "An Approach to the Analysis of Political Systems," in: Milton L. Barron (ed.), Contemporary Sociology: AnIntroduction Textbook of Readings. New Yorkand Toronto: Dodd, Mead \& Company. 
Hosen, Nadirsyah. 2003. "Reform of Indonesian Law in the Post-Soeharto Era (1998-1999)". Disertasi, TidakDiterbitkan. Unversity of Wollongong, Australia.

Isin, E. F. dan Turner, B. S. 2007. “InvestigatingCitizenship: An Agenda for Citizenship Studies". Citizenship Studies, 11(1), 5-17.

Kalidjernih, Fredy Kiran. 2005. “PostColonial Citizenship Education: A Critical Study of the Production and Reproduction of the Indonesian Civic Ideal". Disertasi, Tidak Diterbitkan. Australia: University of Tasmania.

Kidwell,F.L. 2005. “The Relationship between Civic Education and State Policy: An Evaluative Study." Disertasi, Tidak Diterbitkan. Agus Wahyudi: University of Southern California.

Langenberg, M. V. 1990. "The New Order State: Language, Ideology, Hegemony". In: Arief Budiman (ed.). State and Civil Society in Indonesia. Clayton,Victoria: Centre of Southeast Asian Studies, Monash University.

Muchson, 2004. "Pendidikan Kewarganegaraan Paradigma Baru dan Implementasinya dalam Kurikulum Berbasis Kompetensi". Jurnal Civics, 1(1), 29-41.

Osler, A. dan Starkey, H. 2006. “Education for Democratic Citizenship: A
Review of Research, Policy and Practice 1995-2005". Research Papers in Education, 21(1), 433-466.

Patrick, J. J. 1999. “Education for Constructive Engagement of Citizens in Democratic Civil Society and Government," in: Charles F. Bahmueller dan John J. Patrick, Principles and Practices of Education for Democratic Citizenship: International Perspectives and Project, Bloomington, IN: ERIC Clearinghouse for Social Studies/Social Science Education and the ERIC Adjunct Clearinghouse for International Civic Education in Association with Civitas. pp.41-60.

Patrick, J. J. 2002. “Defining, Delivering, and Defending a common Education for Citizenship in a Democracy," makalah disajikan di Summit on Civic Learning in Teacher Preparation, Boston, 15 Mei. dari situs Education Resources Information Center (ERIC), http://eric.ed.gov/ERICWebPortal/contentd elivery/servlet/ERIC Servlet?accno=ED464886 (ED 464886) Diunduh 19 April 2007.

Peraturan Menteri Pendidikan Nasional RINo. 22 Tahun 2006 tentang Standar Isi Satuan Pendidikan Dasar dan Menengah.

Print, M.1999. “Introduction, Civic Education and Civil Society in the Asia-Pacific." In: Murray Print, James Ellickson-Brown and Abdul Razak Baginda. (eds.). Civic 
Education for Civil Society. London: Tilaar, H.A.R. 2006. Standarisasi PendiASEAN Academic Press, pp. 9-18.

Quality Curriculum Association. 1998. dikan Nasional:Suatu Tinjauan Kritis. Jakarta: Rineka Cipta.

Education for Citizenship and the Teaching of Democracy in Schools. London: Quality Curriculum Association.

Wong, K. J. 1995. “The Politics of Education: From Political Science to Interdisciplinary Inquiry". in: Jay D. Scribner dan Donald H. Layton (eds.). The Study of Educational Politics. Washington D.C, dan London: The Falmer Press. 